\title{
TOLERANCE OF MEDICINAL PLANTS TO SOIL ACTIVE HERBICIDES
}

\author{
R.B.MITCHELL and R.J.ABERNETHY
}

\begin{abstract}
AgResearch, Invermay Agricultural Centre, Private Bag 50034, Mosgiel.
SUMMARY

Three trials in Otago evaluated the tolerance of two herbs, valerian (Valeriana officinalis) and dandelion (Taraxacum officinalis) to a range of residual herbicides. In one trial, transplanted valerian showed tolerance to trifluralin applied and incorporated before transplanting and repeated at planting and to linuron, aziprotryne and pendimethalin applied 1 and 4 days after transplanting. Plants exhibited declining tolerance of terbacil, prometryn and chloroxuron. Root dry matter production was significantly reduced by chloroxuron when applied 1 day after transplanting but increased by terbacil when applied 4 days after planting. In two trials direct seeded dandelion emerged and established in plots treated with either trifluralin, aziprotryne, chloroxuron or methabenzthiazuron, producing DM yields similar to, or better than, the standard paraquat/diquat treatment. Plant numbers were significantly reduced by pendimethalin at both trial sites over both years.

Keywords: valerian, dandelion, herbicide, plant numbers, yield
\end{abstract}

\section{INTRODUCTION}

Valerian is a perennial herb indigenous to Eastern and Central Europe. The dried rhizomes and roots are processed for use as a sedative. Oil is obtained from steam distillation of the dried, ground roots and used in the flavour and pharmaceutical industries. Valerian is approved as a GRAS (generally recognised as safe) food ingredient in America (Anon. 1993).

Dandelion is a rosette forming, deep rooting perennial of the compositae family which is under evaluation in New Zealand for medicinal uses. The dried ground roots can be also used as a coffee substitute.

Initial observations (Mitchell and Abernethy, unpublished), indicated that valerian transplants and direct seeded dandelion exhibited acceptable but variable tolerance to a range of short lived residual herbicides recommended for use in valerian crops in Germany and Holland (Maas 1990; Pank et al. 1980). Hartley (1993) demonstrated that valerian could tolerate a range of soil active herbicides applied either before or after transplanting.

This paper reports the findings of further trials in the Otago area to evaluate the tolerance of these two herbs to a range of residual herbicides.

Valerian

\section{MATERIALS AND METHODS}

The valerian trial was sited at Redbank Research Station, Clyde, in Central Otago. Soil type was a Molyneux loamy sand. Plants, varying between $5 \mathrm{~cm}$ and $15 \mathrm{~cm}$ in height, were transplanted into a finely cultivated seed bed on either 9 October (two replicates) or 12 October 1992 (two replicates). Seed bed preparation was completed on the morning of the ninth. Thirty plants (three rows of 10 plants) were placed in a grid pattern at $50 \mathrm{~cm}$ spacings in each $5 \times 1.5 \mathrm{~m}$ plot randomised in four blocks.

Trifluralin (Treflan) was applied and incorporated by rotary hoeing just before the first planting and repeated, being incorporated by raking around the transplants on 13 October when all other treatments (Table 1) were applied using a modified Oxford

Proc. 47th N.Z. Plant Protection Conf. 1994: 183-187 
Precision sprayer fitted with 8002 TeeJet nozzles at $190 \mathrm{kPa}$ in 300 litres/ha. A hand weeded treatment was included as the control. Soil conditions were moist at spraying, $17 \mathrm{~mm}$ of water having been applied by overhead sprinklers in the week before planting. A further $8 \mathrm{~mm}$ was applied between the two planting dates and $16 \mathrm{~mm}$ in the week following the last planting. The number of plants per plot were counted and crop vigour and percentage cover of weeds visually assessed 20 and 28 days after spraying. Final plant counts were taken at harvest in September 1993 (48 weeks after spraying).

\section{Dandelion}

Two sites were used for this investigation, one at Invermay on a Wingatui recent silt loam and the other at Palmerston on a Pomahaka silt loam. The trial area at Invermay was sprayed with paraquat/diquat (Preeglone) on 3 December 1992 to control emerged seedling weeds.

Trifluralin was applied and incorporated and dandelion sown with a Planet Junior on 7 December. The remaining herbicides (Table 2), were applied 2 days later. At Palmerston the crop was drilled using a cone seeder drill on 8 December 1992 and treatments applied 1 day later, immediately after paraquat/diquat was sprayed over the trial area. The paraquat/diquat treatment was used as the standard at both sites. Trifluralin was not used at Palmerston and was not applied at Invermay when treatments were re-applied at both sites in early September 1993. Plot size at Invermay was $3 \times 1.5 \mathrm{~m}$ with treatments randomised within four blocks. At Palmerston plots measured $4.5 \times 1.5 \mathrm{~m}$, treatments being randomised in four replicates along a single drill run. There were three drill rows, each $0.3 \mathrm{~m}$ apart, per plot at both sites. The soil at both sites had been cultivated to a fine tilth and was moist when drilling and spraying were carried out. All plots at both sites were hand weeded in late January 1993 and subsequently as needed. Asulam (Asulox) was blanket sprayed over the trial area at Invermay to control broad-leaved dock on 28 January 1993.

Weed cover was visually assessed at irregular intervals over two seasons at both sites. Vigour of dandelion was rated at Palmerston but not at Invermay. Plant numbers (Table 2) and crop yield (Table 3 ) were determined in three $0.5 \mathrm{~m}$ lengths of drill row/ plot at Invermay in June 1993 and at Palmerston in May 1993 and again at both sites in March 1994. Leaf production was not measured at Palmerston in the second year as flooding had deposited silt over part of the trial.

All data were analysed by standard analysis of variance.

\section{Valerian}

\section{RESULTS}

On 2 November 1992 more dead plants were recorded in plots which had been treated 1 day after planting than in plots treated 4 days after planting in the terbacil (Sinbar), prometryn (Gesagard $50 \mathrm{WP}$ ) and chloroxuron (Tenoran 50 WP) treatments $(\mathrm{P}<0.05)$ (Table 1). Plant numbers continued to decrease in these treatments at both planting times until 10 November 1992. There were no significant $(\mathrm{P}<0.05)$ decreases in plant numbers in any treatment between 10 November 1992 and 13 September 1993 when final counts were taken, and treatment differences remained the same.

Nine weeks after spraying, weed cover in the untreated control plots averaged $38 \%$, and was comprised of fathen (Chenopodium album) nightshade (Solanum spp.) and volunteer chamomile (Matricaria recutita). Galinsoga (Galinsoga parviflora), nightshades and shepherd's purse (Capsella bursa pastoris) averaged $20 \%$ cover in trifluralin treated plots, but plots in all other treatments contained less than $1 \%$ weed cover. The time of herbicide application affected root dry matter production only in the terbacil treatment where later application gave significantly higher yield (Table 1). The dry matter yield from chloroxuron plots was significantly lower than those of aziprotryne (Brasoran 50 WP) and pendimethalin (Stomp 330E) when applied 1 day after planting but no treatment increased the yield relative to the hand weeded plots. Of the treatments applied 4 days after planting only terbacil significantly increased root dry matter yield when compared with the hand weeded control. 
TABLE 1: Valerian plant numbers per plot at two counting dates after application of different herbicides 1 and 4 days after planting (DAP) valerian and dry matter root production $(\mathrm{kg} / \mathrm{ha})$ at harvest on 13 September 1993.

\begin{tabular}{lccccccc}
\hline $\begin{array}{l}\text { Treatment } \\
\text { applied } \\
9 \text { or 15.10.92 }\end{array}$ & $\begin{array}{c}\text { Rate } \\
\mathrm{kg} \mathrm{ai} / \mathrm{ha}\end{array}$ & \multicolumn{2}{c}{2.11 .92} & \multicolumn{2}{c}{10.11 .92} & \multicolumn{2}{c}{13.9 .93} \\
& & 1 DAP1 & 4 DAP1 & 1 DAP & 4 DAP & 1 DAP & 1 DAP \\
\hline $\begin{array}{l}\text { trifluralin } 1 \\
\text { terbacil }\end{array}$ & $0.8+0.8$ & 30 & 30 & 30 & 29 & 2610 & 2800 \\
linuron & 0.75 & 18 & 28 & 7 & 23 & 2020 & 3580 \\
prometryn & 1.0 & 29 & 30 & 27 & 28 & 2940 & 2180 \\
chloroxuron & 1.0 & 22 & 29 & 12 & 23 & 2500 & 3050 \\
aziprotryne & 4.0 & 16 & 30 & 8 & 22 & 1510 & 2980 \\
pendimethalin & 1.5 & 28 & 30 & 27 & 30 & 3250 & 2170 \\
untreated & - & 30 & 29 & 30 & 29 & 3430 & 2340 \\
& & 30 & 30 & 30 & 2010 & 2060 \\
LSD (<0.05) between rows & 3.39 & & 4.71 & & 1450 \\
& between columns & 3.57 & & 4.98 & & 1540 \\
\hline
\end{tabular}

1 trifluralin was applied and incorporated into the soil just before the first planting (9.10.92) and re-applied with other herbicides (13.10.92)

TABLE 2: Dandelion plant numbers per $1 \mathrm{~m}$ of row from two harvests at two sites after two applications of different herbicides. Dandelion sown on $7 / 8.12 .92$.

\begin{tabular}{|c|c|c|c|c|c|}
\hline \multirow{2}{*}{$\begin{array}{l}\text { Treatment applied } \\
9.12 .92 \text { and }\end{array}$} & \multirow{2}{*}{$\begin{array}{c}\text { Rate } \\
\mathrm{kg} \text { ai/ha }\end{array}$} & \multicolumn{2}{|c|}{ Invermay } & \multicolumn{2}{|c|}{ Palmerston } \\
\hline & & 1993 & 1994 & 1993 & 1994 \\
\hline trifluralin 1 & 0.8 & 32 & 28 & - & - \\
\hline aziprotryne & 3.0 & 22 & 29 & 47 & 48 \\
\hline chloroxuron & 3.0 & 32 & 38 & 19 & 21 \\
\hline methabenzthiazuron & 0.7 & 31 & 33 & 45 & 37 \\
\hline pendimethalin & 1.5 & 6 & 10 & 4 & 12 \\
\hline paraquat/diquat ${ }^{2}$ & $0.5 / 0.3$ & 27 & 26 & 54 & 55 \\
\hline $\operatorname{LSD}(<0.05)$ & $\begin{array}{l}\text { tween rows) } \\
\text { tween columns) }\end{array}$ & & & & \\
\hline
\end{tabular}

1 applied 7.12 .92

2 applied 3.12.92

\section{Dandelion}

The percentage ground cover of annual weeds at Palmerston was $38 \%$ in the paraquat/diquat treatment and $19 \%$ in the methabenzthiazuron treatment 6 weeks after spraying, but there was less than $4 \%$ cover in each of the other treatments. At Invermay, annual weeds covered $14 \%$ of the area in the paraquat/diquat treated plots and less than $7 \%$ in each of the other treatments 8 weeks after spraying. However, seedling dock (Rumex obtusifolius) had emerged in the paraquat/diquat, methabenzthiazuron(Tribunil) and aziprotryne plots covering $54 \%, 38 \%$ and $21 \%$ respectively at this time. Trifluralin, pendimethalin and chloroxuron treatments were associated with dock cover of less than 5\%. Following the second herbicide application at Invermay (6 September 1993), white clover (Trifolium repens) became dominant in the paraquat/diquat, pendimethalin and methabenzthiazuron plots and by 7 December 1993 clover ground cover averaged 
$66 \%$ in the paraquat/diquat treatment, $40 \%$ in pendimethalin and $36 \%$ in the methabenzthiazuron treated plots. Plant numbers were similar in both years for all treatments at each site (Table 2). Leaf production from each treatment in 1994 was significantly higher than 1993 at Invermay and root yields were significantly higher at both sites in year two (Table 3 ).

At Invermay in 1993, trifluralin, chloroxuron and methabenzthiazuron treated plots produced significantly more leaf than the standard paraquat/diquat treatment $(\mathrm{P}<0.05)$. This was repeated in the trifluralin treated plots in 1994. Pendimethalin was associated with significantly reduced leaf yields in both years at this site. All treatments other than pendimethalin significantly increased root yield in one or both years compared to the standard paraquat/diquat treatment (Table 3). At Palmerston, none of the herbicides produced significantly higher leaf or root dry matter yields than the paraquat/diquat treatment in either year but pendimethalin was again associated with reduced leaf yield (Table 3 ).

TABLE 3: Dandelion leaf and root yields ( $\mathrm{kg} \mathrm{DM} / \mathrm{ha}$ ) from two sites.

\begin{tabular}{|c|c|c|c|c|c|c|c|c|}
\hline \multirow[t]{3}{*}{ Treatment } & \multicolumn{4}{|c|}{ Leaf } & \multicolumn{4}{|c|}{ Root } \\
\hline & \multicolumn{2}{|c|}{ Invermay } & \multicolumn{2}{|c|}{ Palmerston } & \multicolumn{2}{|c|}{ Invermay } & \multicolumn{2}{|c|}{ Palmerston } \\
\hline & 1993 & 1994 & 1993 & 1994 & 1993 & 1994 & 1993 & 1994 \\
\hline trifluralin & 2290 & 4570 & - & - & 4070 & 9660 & - & - \\
\hline aziprotryne & 1680 & 2740 & 5160 & - & 1800 & 10160 & 3720 & 8620 \\
\hline chloroxuron & 2240 & 3250 & 3670 & - & 3870 & 8580 & 2840 & 9750 \\
\hline methabenzthiazuron & 1880 & 3280 & 4580 & - & 3150 & 6640 & 3390 & 9640 \\
\hline pendimethalin & 990 & 2320 & 700 & - & 1080 & 5960 & 790 & 7900 \\
\hline paraquat/diquat & 1030 & 3830 & 3880 & - & 1670 & 6310 & 3260 & 8910 \\
\hline \multicolumn{9}{|l|}{$\operatorname{LSD}(<0.05)$} \\
\hline (between rows) & \multicolumn{2}{|c|}{663} & \multicolumn{2}{|c|}{1676} & \multicolumn{2}{|c|}{1294} & \multicolumn{2}{|c|}{3715} \\
\hline (between column & \multicolumn{2}{|c|}{760} & \multicolumn{2}{|c|}{-} & \multicolumn{2}{|c|}{1428} & \multicolumn{2}{|c|}{3102} \\
\hline
\end{tabular}

\section{DISCUSSION}

Valerian transplants showed acceptable tolerance to a range of soil active herbicides applied after planting. However, it appears that herbicide application should be delayed long enough to allow disturbed soil to settle around the plants before application, thereby lessening the risk of herbicides being carried to the root zone. In this trial, a combination of loose soil and moist conditions coupled with over-head watering soon after spraying, appears to have assisted herbicide movement in some treatments when applied 1 day after planting, resulting in reduced plant numbers. There was no relationship between plant numbers and root dry matter yield for which there is no obvious explanation.

Dandelion grew well at both sites but as has been found in previous work (Mitchell and Abernethy, unpublished), seedling establishment can be affected by residual herbicides applied pre-emergence on light soils. In 1994, dandelion leaves effectively smothered annual weeds, but competition from clover may have affected root yield at Invermay. Plant densities within the range encountered in this investigation do not appear to have influenced root dry matter production, but did influence root shape with more forked roots occurring where plant numbers were low.

Both valerian and dandelion tolerated a range of herbicides which also controlled weeds common to all sites.

\section{ACKNOWLEDGEMENTS}

The authors would like to thank Mr. D. Taylor and Miss. J.A. Shand for technical assistance, Mr. P.D. Johnstone for statistical analyses, and Mr. C.M. Ferguson and Mr. R.F. van Toor for criticism of the manuscript; Crop and Food Research Institute for financial support, through FRST. 


\section{REFERENCES}

Anon., 1993 Valerian - Valerian officinalis L. Crop and Food Research, Broadsheet Number 34, July 1993

Hartley, M,J., 1993. Herbicide tolerance of and weed control in three medicinal herbs. Proc. 37th N.Z. Plant Protection Conf.; 30-34

Maas, G., 1989. Official and not registered herbicide recommendations for vegetable crops, herbs and medicinal plants. International Soc. for Hort. Science and European Weed Res. Soc., 4th issue, $66 \mathrm{pp}$.

Pank, F., Hannig, H.J., Hauschild, J. and Zygmunt, B., 1980. Chemical weed control in medicinal plants. Part 1 Valerian. Pharmazie 35(2): 115-119. 